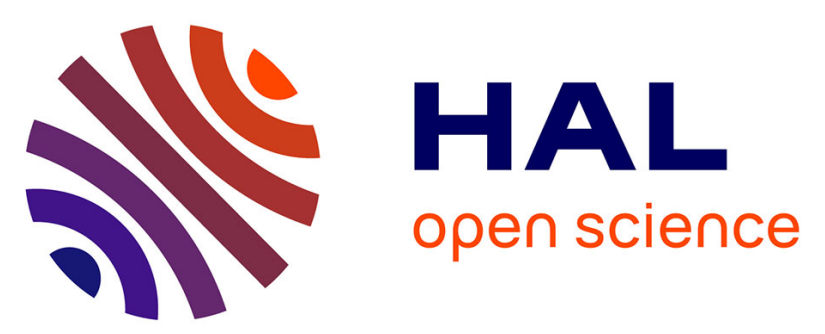

\title{
XAFS Study on Decomposition of Molybdenum Dialkyl Phosphorodithioate in Commercial Engine Oils
}

\author{
T. Okamoto, K. Fujita, M. Kawamura
}

\section{To cite this version:}

T. Okamoto, K. Fujita, M. Kawamura. XAFS Study on Decomposition of Molybdenum Dialkyl Phosphorodithioate in Commercial Engine Oils. Journal de Physique IV Proceedings, 1997, 7 (C2), pp.C2-1259-C2-1260. 10.1051/jp4:19972222 . jpa-00255296

\section{HAL Id: jpa-00255296 https://hal.science/jpa-00255296}

Submitted on 1 Jan 1997

HAL is a multi-disciplinary open access archive for the deposit and dissemination of scientific research documents, whether they are published or not. The documents may come from teaching and research institutions in France or abroad, or from public or private research centers.
L'archive ouverte pluridisciplinaire HAL, est destinée au dépôt et à la diffusion de documents scientifiques de niveau recherche, publiés ou non, émanant des établissements d'enseignement et de recherche français ou étrangers, des laboratoires publics ou privés. 


\title{
XAFS Study on Decomposition of Molybdenum Dialkyl Phosphorodithioate in Commercial Engine Oils
}

\author{
T. Okamoto, K. Fujita and M. Kawamura
}

Toyota Central Research and Development Laboratories Inc., Aza Yokomichi, Oaza Nagakute, Nagakute-cho, Aichi-gun, Aichi 480-11, Japan

\begin{abstract}
The local structure around Ho atoms in fuel-saving englne olls has been invest lgated by XAFS using laboratory scale equipment. The EXAFS results suggest that the local structure of the Mo atoms in fresh englne oils is simllar to that in the molybdenum dialkyl phosphorodithioate. It is also suggested that the nolybdenum compound in the olls changes to a Mo oxide in which a Mo aton is coordinated by six oxygen atoms after $2000 \mathrm{~km}$ running. XANES spectra of the compounds show that the coordination geometry around the $H_{0}$ atoms in the $\mathrm{Ho}_{0}$ oxide is simllar to that in $\mathrm{NoO}_{3}$ rather than $\mathrm{HoO}_{2}$. The deterioration of anti-friction effect of the englne olls after use colncides with Mo oxide formation.
\end{abstract}

\section{INTRODUCTION}

Cooling, sealing, an anti-corrosion abllttles, as well as good lubricating abllity, are required for englne olls. Different kinds of additives are usually mixed with englne oils for these purposes. A conmerclal eng ine oll including a small quantity of organlc molybdenum conpound as an ant i-frictlon additive has recently been placed on the market. However, the additive effect on the anti-friction decreased with car running and was lost after $4000 \mathrm{~km}$ runing. Therefore, the Information of the structure around Mo atoms in the oils is very important to develop an anti-frictlon engine olls. in the present study, the local structure around a Mo atom in an engine oil containing an organic molybdenum compound has been invest igated by measuring Mo-K absorpt ion spectra.

\section{EXPERIMENTAL}

\section{1 Samples}

Different kinds of comercial engine oils containing a small quantity of organic molybdenum compound (about $0.02 \% t . \%$ of $M o$ ) were used for car ruming and subjected to XAFS measurements. The lubrication ability of the engine olls after car runing was estloated using a crossed-pin type lubricant tester. The results of the lubrication tests for the engine oils with and without a Mo compound and the engine olls used for XAFS measurements are shown in Figure 1.

The Mo-K XAFS of the engine oils before and aftet the car running were measured. Mo metal foil $(35 \mu m$ thick), Mo-DTP additive (containing about $9 \mathrm{wt} . \%$ of $\mathrm{Mo}$ ), and extra pure $\mathrm{HoO}_{2} \mathrm{MOO}_{3}$, and $\mathrm{MoS}_{2}$ were used as reference materials in this study.

2-2 Measurement

$X A F S$ spectra in the vicinity of the Wo-K absorption edge vete measured in transmission mode. An $X-r a y$ generator with a Cu rotating anode was operated at $40 \mathrm{kV}-180 \mathrm{~m} \Lambda$. Cont inuous $\mathrm{X}-\mathrm{tay} f \mathrm{f}$. monochromatlzed by a Ge(220) Johansson type bent crystal. The intens ties of the incident $X$-ray beam (I $)$ transmitted bean (I) were measured by an lonization chamber and a solid state detector,

respectively. A sample holder vith an $X$-ray pass length of $60 \mathrm{~mm}$ was used to measure the $X-t a y$ absorption spectrum of a small quantity of Mo in the engine oll. The energy region to measure the spect ta was divided into three parts ; the low energy side of the edge (19.4-19.8keV), the hlgh energy side (20.7$21.0 \mathrm{keV})$, and near the absorption edge $(19.8-20.7 \mathrm{keV})$, and the stepping width of each energy tegion ras set at $30 \mathrm{eV}, 6 \mathrm{eV}$, and $2.5 \mathrm{eV}$, respectively. The $X-t a y$ intensity at each different data point was measured using the fixed time method.

\section{RESULTS AND DISCUSSION}

\section{1 EXAFS}

Curve fitting analysis was performed to obtain structural paraneters. The curve fitting results are shown in Table 1 , suggesting the following points for the Mo compound af ter car running.

(1)The second and third peaks corresponding to Mo-S and Mo-Mo pairs, respectlvely, disappeared with an

increase in the car running distance, and the position of the first peak corresponding to the Mo-0 pair changed with cat running.

(2)The bonds between the Mo atom and the coordinated oxygen atoms in olls $A$ and $B$ after $4000 \mathrm{~km}$ car running are ascribed to $\mathrm{Mo}-0$ or $\mathrm{MO}_{0}-\mathrm{OH}$ and $\mathrm{MO}_{0}=0$, respectively, because their interatonic distances of 2.06 and $1.65 \mathrm{~A}$, respectively, are close to the values for single and double bonds for a Mo-0 pair. In all cases, it was found that the structure of the Mo compound added to the engine oll as an ant $1-$ frictlon additive was dissociated by the car running about $2000 \mathrm{~km}$, and that the liberated Mo atom subsequently combines with six oxygen atoms. It seems that most of the Mo coordinated by six oxygen atoms is dispersed at random in the oll because a peak due to the Mo-Mo pair is not observed in the Foutler transforms. 
3. 2 XANES

The derivative XANES spectra are shown in Figures 2 and 3 . These derivative spectra showed the following:

(1) The two kinds of engine olls, $A$ and $B$, are slmilar to each other in the Inltial state.

(2) The curves after car running are also similar to each other, and to that of $\mathrm{MOO}_{3}$ in which the Mo atom is sur rounded by six oxygen atoms.

Although a $\mathrm{Wo}$ atom in crystalline $\mathrm{MOO}_{2}$ differs from that of a $\mathrm{Ho}$ atom in crystalline $\mathrm{MoO}_{3}$, the interatomic distances between the Mo atom and oxygen atoms in the crystalline $\mathrm{MoO}_{2}$ have an anisotropic distribution in a range from 1.84 to $2.34 \mathrm{~A}$. Thile, those of $\mathrm{MoO}_{3}$ have a relatively isotropic

distribution in a range of from 1.94 to $2.07 \mathrm{k}$. Fron the crystallographic knowledge, we can say that the geometrical local structure around the Mo atom in the engine oll after the car running is similar to that in crystalline $\mathrm{MOO}_{3}$ compared to that in crystalline $\mathrm{MOO}_{2}$.

These XANES results are also supported by the results of the EXAFS analysis.

\section{CONCLUSION}

The Mo-K absorption measurements were carrled out using laboratory scale XAFS equipment to analyze the deterioration mechanism of the commerclal engine olls containing a small quantity of organic molybdenum compound. The results obtained ate summarized as follows:

(1)The local structure around a Mo atom in the engine oils at the initial state is basically simllar to that of the Mo-DTP additive.

(2)The local structure around Mo in the engine oils is changed after car running. The liberated Mo atom produced by the dissoclation is coordinated by six oxygen atoms. The oxygen coordination of the Mo atom is similar to that in the crystalline $\mathrm{MoO}_{3}$.

(3)The structural change of the Mo compound is related to the friction coefficient. Therefore, the deterloration in the anti-friction effect of the engine oils after car running colncides with Mo oxide formation.

(4)I $\mathrm{t}$ is found that even a small quantity of elements may be measured by XAFS. The laboratory scale XAFS equipment was verlfied to be useful in determining the local structure of dilute system.

Acknowledgments

The authors are grateful to Prof. H. Wakita (Fukuoka Univ.) for useful discussions.

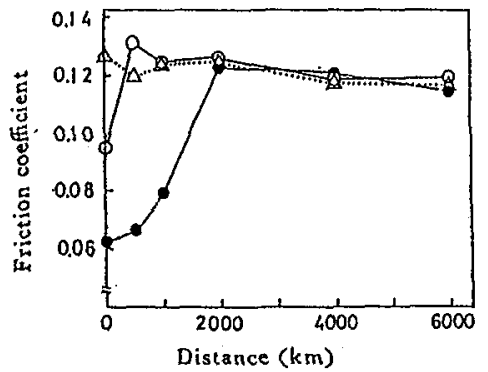

Figure 1 : Change of the friction coefficient during car running. [O:011(A), :011 (B), $\triangle$ : Mo f tee oll]

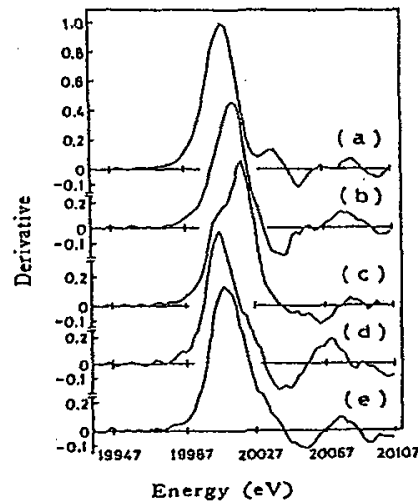

Figure 2 : Derivative curves for the references. $\left[\mathrm{a}: \mathrm{Mo}_{1} \mathrm{~b}: \mathrm{MoO}_{2}, \mathrm{c}: \mathrm{MoO}_{3}, \mathrm{~d}: \mathrm{MoS}_{2}\right.$ e $: \mathrm{Mo}^{-} \mathrm{DTP}$ additive]
Table 1: Curve fitting results

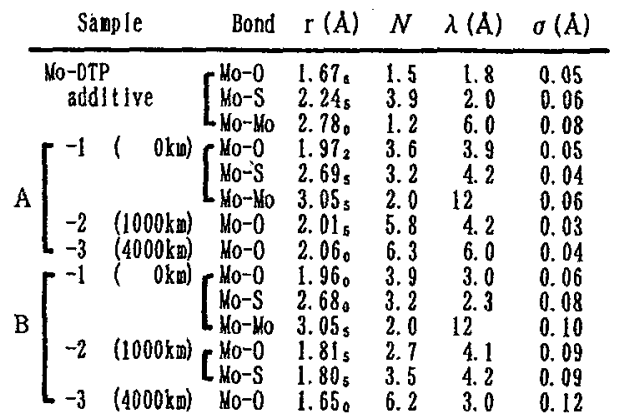

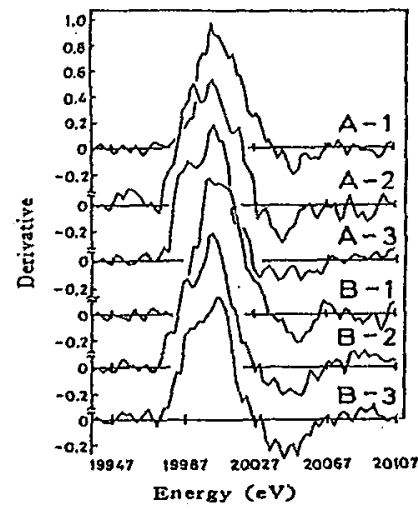

Figure 3 : Derlvatlve curves for the engine olls. $[A-1,-2$ and $-3: 011(\mathrm{~A}), \mathrm{B}-1,-2$ and $-3: 011(\mathrm{~B})]$ 